\title{
WPEYW WOJEN PÓŁNOCNYCH XVII I XVIII W. NA POSTAWY I RELACJE MIESZKAŃCÓW POZNANIA RÓŻNYCH WYZNAŃ
}

\author{
ABSTRACT \\ Impact of the Northern Wars of the Seventeenth and Eighteenth Centuries \\ on Attitudes and Relations Between Various Religious \\ Denominations Among Poznań Burghers
}

Wars often result in changes of peoples' attitudes and approach towards others and social, economic and religious reality around them. This is especially true among those who have personally experienced atrocities of military conflicts. The aim of this paper is to reveal the impact of the Northern Wars (i.e. the 1655-1660 and 1700-1712 conflicts) on attitudes and relations between burghers of the city of Poznań representing various religious denominations. Examination of evidence shows that citizens of Poznan displayed usually toleration for other religions groups. This circumstance, of course, did not exclude occasional religious upheaval.

Key words: Swedish Deluge (invasion), Great Northern War, Protestants, Catholics, Jews, attitudes, relations

Słowa kluczowe: potop szwedzki, wielka wojna północna, protestanci, katolicy, Żydzi, postawy, relacje

Rocznice wielkich wydarzeń historycznych mających w przeszłości wpływ na życie codzienne mieszkańców Europy są dobrą okazją do przyjrzenia się pewnym aspektom następstw tych ważnych momentów w historii. O konsekwencjach globalnych do tej pory powstało dużo prac, jednak o rezultatach dla małych społeczności - nie tak wiele. W związku z tym warto na poziomie regionalnym podjąć temat stosunków mieszkańców jednego miasta - z tej racji podjęto próbę opisania oddziaływania dwóch wojen północnych, czyli 
tzw. potopu szwedzkiego z lat 1655-1660 i wielkiej wojny północnej 1700-1721, na wzajemne relacje mieszkańców Poznania różnych wyznań, a także ich stosunek do okupantów. Warte podkreślenia jest to, iż praca ta ma dotyczyć mieszczan żyjących w Poznaniu w XVII i XVIII w. Ukazać ma wzajemny stosunek do siebie obywateli poznańskich różnych wyznań, a także odnoszenie się do okupantów, czyli efekt wojen, które dotknęły miasto. Samo miasto doświadczyło działań zbrojnych i okupacji w latach 1655-1657 i 1703-1716. Natomiast, aby dobrze zrozumieć temat, należy cofnąć się aż do roku 1517, a mianowicie do wystąpienia Marcina Lutra i lawiny zmian, które ono przyniosło. Poznań też znalazł swoje miejsce w tych przemianach religijnych. Z uwagi na to praca została skonstruowana tak, żeby Czytelnik poznał zarys historii reformacji i kontrreformacji w Poznaniu, a następnie sytuację w mieście podczas okupacji szwedzkiej i przebywania w nim garnizonu saskiego w trakcie wielkiej wojny północnej. Rozmaite wydarzenia, które miały miejsce w Poznaniu i w których uczestniczyli protestanci, katolicy i Żydzi, odbijały się na ich wzajemnym postrzeganiu. Celem pracy jest przedstawienie wpływu wojen na postawę i wzajemne relacje mieszkańców Poznania. W związku z tym należy postawić tezę, iż mimo ciężkich doświadczeń mieszkańcy Poznania w większości byli ludźmi tolerancyjnymi w stosunku do współobywateli, a ponadto nie udało się dysydentów nastawić przeciwko katolikom, a katolików przeciwko dysydentom. Inna za to była reprezentowana postawa kleru katolickiego i szlachty. Sami protestanci, związani z Poznaniem od pokoleń, dochowywali wierności rodzinie, miastu oraz państwu, w którym znaleźli dom. Aczkolwiek do złej opinii o innowiercach przyczyniali się „świeżo” przybyli protestanci z krajów niemieckich ${ }^{1}$, zmuszeni do opuszczenia swoich domów w trakcie działań wojny trzydziestoletniej i szukający w Rzeczypospolitej schronienia. Ich opinie oddziałały na wzajemne relacje. Zupełnie inny stosunek był do ludności żydowskiej, ale o tym niżej.

Cenną pracą omawiającą rolę i postawy dysydentów w Poznaniu jest książka autorstwa Olgierda Kieca², która przybliża dzieje protestantyzmu w mieście od XVI w. do czasów współczesnych. Ważne okazały się kroniki klasztorów poznańskich, pozwoliły one odtworzyć fakty z życia mieszkańców miasta i oczywiście samych klasztorów, które mocno ucierpiały w wyniku wojennej zawieruchy ${ }^{3}$. Przydatne były m.in. prace Mariana K. Miki w których znajdujemy wypisy z dokumentów sporządzonych w Poznaniu mówiących o sytuacji w mieście i stanie samego Poznania, jak również materiały źródłowe z Archiwum

1 Pierwsza grupa braci czeskich i ewangelików z Czech i ze Śląska, uciekających przed wojną trzydziestoletnią, znalazła się w Poznaniu w $1634 \mathrm{r}$.

2 O. Ki e c, Historia protestantyzmu w Poznaniu od XVI do XXI wieku, Poznań 2015.

3 Kronika poznańskich Karmelitów Bosych, oprac. P.F. Ne u m a n n OCD, Poznań 2001, Kroniki staropolskie; Kronika Benedyktynek poznańskich, oprac. A.B. Tomczak OFM, J. Wiesiołowski, Poznań 2001, Kroniki staropolskie; Kronika Bernardynów poznańskich, oprac. A.B. To m c z a k OFM, J. W i s s i o o w ski, Poznań 2002, Kroniki staropolskie.

4 Opisy i lustracje Poznania z XVI-XVIII wieku, oprac. M.J. Mi ka, Poznań 1960. 
Państwowego w Poznaniu oraz wiele prac, które przywoływały wydarzenia rozgrywające się w Poznaniu w omawianym czasie oraz zakresie.

Na rozwój reformacji w Wielkopolsce wpływ miała m.in. średniowieczna kolonizacja niemiecka, ponieważ dzięki powiązaniom rodzinnym, kulturowym i językowym „nowinki” religijne najszybciej docierały do niemieckojęzycznej ludności Wielkopolski. Dodatkowo graniczenie z regionami, które wcześnie przyjęły reformację, a więc z Pomorzem Zachodnim, Nową Marchią, Brandenburgią i księstwami śląskimi, spowodowało, że jeszcze zanim powstał oficjalny Kościół luterański, hasła reformacji szerzyły się (spontanicznie) wśród szlachty i mieszczan (w mniejszej mierze wśród chłopów) $)^{5}$. Echa reformacji dotarły do Poznania już kilka tygodni po wystąpieniu Marcina Lutra w Wittenberdze ${ }^{6}$. Potem w ciągu kilku lat zaczęły do miasta docierać pisma Lutra, które przywozili ze sobą kupcy i studenci niemieckich uczelni. Była to przeważnie literatura niemiecka ${ }^{7}$. Głównymi jej odbiorcami byli studenci i duchowieństwo. Pozostali mieszkańcy Poznania stykali się z ideami reformacyjnymi, słuchając kazań. Wielu duchownych opowiedziało się po stronie nowych idei. Już w latach 1525-1526 w farze, za zgodą rady miejskiej, nauki reformacyjne głosił po niemiecku Jan z Bambergu'. W latach 1538-1540 kazania, już po polsku, wygłaszał w tym samym kościele Stanisław z Przybysławka. Po jego usunięciu miejsce kaznodziei w farze zajął Andrzej Samuel, który mimo protekcji biskupiej głosił słowa w duchu nauki Lutra, dlatego też i on został usunięty'. Ważną rolę w początkach reformacji w Poznaniu odegrał także Krzysztof Hegendorfer, który w 1529 r. objął stanowisko profesora Akademii Lubrańskiego. Jemu to Akademia zawdzięczała rozkwit i renesansowy program nauczania. Hegendorfer został jednak usunięty ze stanowiska już w $1535 \mathrm{r}^{10}$ Głoszone idee reformacji doprowadziły w Poznaniu do zamieszek w 1546 r. skierowanych przeciwko katolikom. Toteż Kościół nie miał zamiaru biernie przyglądać się szerzeniu w Poznaniu nauk Lutra i podjął energiczną kontrakcję, wykluczając nieprawomyślnych księży oraz konfiskując literaturę protestancką, przeprowadzając nawet rewizje w domach mieszczan. Skonfiskowane księgi trafiały na stosy, a ich właściciele stawali przed sądem. Protestanci zyskali jednak potężnego sojusznika w postaci kilku wielkopolskich rodów magnackich sprzyjających reformacji bądź wprost wyznających luteranizm. Były to rody: Górków, Ostrorogów,

5 J.Dworzaczkowa, Reformacja a problemy narodowościowe w przedrozbiorowej Wielkopolsce, „Odrodzenie i Reformacja w Polsce" 1978, t. 23, s. 82.

6 Jolanta Dworzaczkowa uważa, że reformacja najpierw dotarła do polskiej elity intelektualnej i społecznej, a do szerszych mas przeniknęła z opóźnieniem 20-30 lat. W Poznaniu natomiast niewielkie grupy wyznaniowe (różnowiercze) tworzyły się spontanicznie od samego początku. Zob. J. D wo r za czk kowa, Reformacja a problemy narodowościowe..., s. 82.

Dzieje Poznania do roku 1793, t. 1, red. J. To polsk i, Warszawa-Poznań 1988, s. 493.

8 O. Ki ec, op. cit., s. 22.

9 Ibidem.

10 Ibidem, s. 23. 
Tomickich i Leszczyńskich, które wzięły w opiekę wielkopolskich protestantów. Górkowie udostępniali nadto swoją kamienicę, a później pałac w Poznaniu na cele protestanckiego kultu religijnego ${ }^{11}$. Do grona innowierców w Poznaniu w roku 1548 dołączyła grupa braci czeskich. Mimo surowych norm moralnych oraz prostoty życia cieszyli się oni sympatią części szlachty wielkopolskiej i mieszczaństwa. Bracia czescy osiedlili się za murami miasta, na Wzgórzu św. Wojciecha, gdzie uzyskali pewne nieruchomości przekazane przez Ostrorogów i dzięki przywilejowi królewskiemu wyjmującemu ten obszar spod władzy miejskiej i duchownej zbudowali w 1564 r. dwa zbory - jeden dla wyznawców modlących się po polsku, a drugi dla Niemców - poza tym szkołę, szpital, założyli też cmentarz ${ }^{12}$.

W drugiej połowie XVI w. reformacja w Poznaniu wyraźnie wytracała impet. Mieszczaństwu Poznania, rywalizującemu już nie z Kościołem, a częściej ze szlachtą, przeszkadzał fakt protegowania protestantów przez szlachtę i magnaterię. Protestanci zaczęli być postrzegani jako ci, którzy rozbijają solidarność stanu mieszczańskiego. Katolicy otrzymali wkrótce potężnego sojusznika w postaci nowego, prężnie rozwijającego się zakonu Towarzystwa Jezusowego. Jezuici trafili do Poznania w 1571 r., sprowadzeni przez biskupa Adama Konarskiego, zdecydowanego przeciwnika reformacji. Dwa lata później otworzyli kolegium w Poznaniu. Szkoła ta cieszyła się tak wielkim prestiżem, iż nawet protestanci wysyłali tam swoich synów, którzy opuszczali szkołę jako gorliwi katolicy ${ }^{13}$. Józef Łukaszewicz, oceniając kolegium jezuickie, napisał: „Gorszy jeszcze wpływ na los kraju wywierała szkoła jezuicka przez swoję niekarność. Albowiem Jezuici dla przywiązania ku sobie uczniów, patrzeli przez szpary na ich najwyuzdańszą swawolą, owszem, gdy jaki zamiar ich tego wymagał, zachęcali młodzież swoję wprost lub ubocznie do wszelkich bezpraw. Młodzież ta wyszedłszy ze szkół, robiła burdy, wrzawy, nieład i bezprawia, do których z młodości nawykła [...]"14. Słowa te odnosiły się tak do Poznania, jak i całej Rzeczypospolitej. Łukaszewicz zaakcentował, że nie było w Poznaniu roku, aby studenci szkoły jezuickiej nie dopuścili się jakiegoś „bezprawia na dysydentach”, Żydach, rzemieślnikach i dostojnikach miejskich. Za przyzwoleniem zakonników młodzież ucząca się w kolegium atakowała różnowierców. A ze względu na to, iż była pod opieką jezuitów, nie dosięgały ją żadne kary. Można stwierdzić, że jezuici ją do tego zachęcali. Polemika jezuicka oddziaływała również na niższe oraz mało wykształcone warstwy mieszczańskie, które wraz z uczniami kolegium jezuickiego wdawały się w antyprotestanckie i antyżydowskie tumulty. Kolejny cios dla poznańskich protestantów stanowiła śmierć Zygmunta Augusta oraz wymarcie w 1592 r. rodu Górków i powrót do Kościoła katolickiego części rodzin magnackich,

11 Ibidem, s. 23-24.

12 Dzieje Poznania do roku 1793, s. 496.

13 O. Kiec, op. cit., s. 26.

14 J. Łukaszewicz, Obraz historyczno-statystyczny miasta Poznania w dawniejszych czasach, t. II, Poznań 1838, s. 23. 
dotąd sprzyjających reformacji. Rywalizacja i spory pomiędzy luteranami a kalwinami i innymi grupami wyznaniowymi także nie sprzyjała protestantom. Już w roku 1592 doszło do pierwszego tumultu antyprotestanckiego. Następne wybuchały w latach: 1596, $1603,1605,1606,1614$ i 1616. Podczas zamieszek z 1616 r. spalono zbory protestanckie na Wzgórzu św. Wojciecha. Głównymi uczestnikami zajść antyprotestanckich byli wspomniani uczniowie kolegium jezuickiego. Nie można ich jednak było postawić przed sądem, gdyż uczniowie podlegali jurysdykcji rektora kolegium, który patrzył przez palce na wybryki swoich podopiecznych. Zburzonych zborów na Wzgórzu św. Wojciecha już nie odbudowano. Na ich miejscu zbudowano kościół i klasztor zakonu karmelitów bosych, sprowadzonych do Poznania w 1618 r. Pałac zaś Górków, w którym odbywały się nabożeństwa protestanckie, odziedziczyli Czarnkowscy, którzy przekazali go benedyktynkom w 1607 r. $^{15}$

Kolejnym uderzeniem w poznańskich protestantów był zakaz dopuszczania ich do prawa miejskiego wprowadzony w 1619 r. Kwestia wyznaniowa już od schyłku XVI w. coraz częściej była warunkiem uzyskania prawa miejskiego, czyli pełnoprawnego obywatelstwa w miastach Rzeczypospolitej ${ }^{16}$. W 1634 r. uchylono wprawdzie zakaz przyjmowania ewangelików do prawa miejskiego Poznania, ale nadal nie zezwalano im na odprawianie nabożeństw w granicach miasta. Z pomocą przyszedł im wojewoda kaliski Zygmunt Grudziński, który mimo że sam był katolikiem, zezwolił na wybudowanie w swoich dobrach, niedaleko Swarzędza, zboru ewangelickiego, w którym modlili się protestanci z Poznania i okolic ${ }^{17}$. W praktyce zresztą zakaz przyjmowania do prawa miejskiego protestantów nie miał żadnego znaczenia. Jak wynika z ksiąg przyjęć do prawa miejskiego i ustaw cechowych, wymagano jedynie, aby wstępujący niekatolik był znany oraz ceniony albo aby był „prawdziwym patriotą”. Podstawowymi czynnikami, które wytworzyły w społeczeństwie poznańskim ten stan tolerancji religijnej, były racje zawodowe i rodzinne. W samym mieście obserwujemy stałą współpracę gospodarczą, handlową i kredytową między przedstawicielami różnych wyznań. Podobnie przy zawieraniu małżeństw - kiedy żona przyjmowała religię męża, do spraw religijnych nie przywiązywano większej wagi, a starano się zasadniczo o najkorzystniejsze połączenie kapitałów. Zdarzały się małżeństwa mieszane religijnie, co oczywiście niechętnie było widziane przez duchownych, szczególnie protestanckich, ponieważ, jak pisze Jolanta Dworzaczkowa, np. niejaki Samuel Mielęcki wyrażał obawę, że po jego śmierci żona katoliczka może sprowadzić katolickiego księdza do kościoła w Mielęcinie ${ }^{18}$. Co ciekawe, w kontaktach handlowych z szerszym rynkiem regionalnym

15 Dzieje Poznania do roku 1793, s. 503.

16 M. Bogucka, H. Samsonowicz, Dzieje miast i mieszczaństwa w Polsce przedrozbiorowej, Wrocław 1986, s. 465.

17 O. Kiec, op. cit., s. 34-35.

18 J. Dworzaczkowa, Konwersje na katolicyzm szlachty ewangelickiej wyznania czeskiego w Wielkopolsce $w$ XVI i XVII wieku, „Odrodzenie i Reformacja w Polsce” 2006, t. 50, s. 94. 
i krajowym największe znaczenie dla Poznania miały ośrodki, w których najbardziej czynną gospodarczo część ludności stanowili kalwini i luteranie ${ }^{19}$. Dotyczyło to powiązań rodzinnych. Sytuacja poznańskich protestantów w pierwszej połowie XVII w., choć trudna i daleka od równouprawnienia, nie była gorsza niż w krajach sąsiednich czy innych miastach Rzeczypospolitej. Podczas tumultów wyznaniowych zginęło w Rzeczypospolitej niewiele osób, a w samym Poznaniu prawdopodobnie nie było ofiar śmiertelnych, gdyż nie ma żadnych na ten temat informacji ${ }^{20}$.

Przechodząc do głównej kwestii niniejszej pracy, należy podkreślić, iż sytuacja protestantów nie tylko w Poznaniu, ale i w całej Rzeczpospolitej pogorszyła się wraz z najazdem szwedzkim z 1655 r. Propaganda kontrreformacyjna chciała w nim widzieć wojnę religijną między katolicką ludnością polską a szwedzkimi luteranami. Starano się przedstawić zamieszkujących Rzeczpospolitą różnowierców jako zdrajców kolaborujących z najeźdźcą. Owszem, część protestantów przeszła na stronę Karola X Gustawa, lecz pod opiekę króla szwedzkiego oddała się także duża część katolickiej szlachty i magnaterii polsko-litewskiej. Zebrana pod Ujściem polska szlachta nie wykazała woli walki ze Szwedami, którzy bez przeszkód wkroczyli do Poznania. Przyczynili się do tego wojewodowie podlaski Jan Piotr Opaliński i kaliski Andrzej Karol Grudziński, którzy wymusili na mieście poddanie się, gdy jego mieszkańcy wcale tego nie chcieli ${ }^{21}$. Ostatecznie Szwedzi do Poznania weszli 29 lipca 1655 r. Na podkreślenie zasługuje fakt, iż Jan Kazimierz zawiódł wówczas oczekiwania poddanych i nie zasługiwał w oczach szlachty na poparcie. W Kronice poznańskich Karmelitów Bosych można odnaleźć stwierdzenie: „Nasi ojcowie, zdradzeni przez polskich magnatów, dzięki miłosierdziu Bożemu znaleźli łaskę w oczach książąt i arystokratów Szwecji i przez szwedzkiego komendanta Poznania [...] byli traktowani uprzejmie"22. Chociaż bardzo szybko doszło do przymusowych kwaterunków żołnierzy, grabieży żywności oraz rekwizycji w klasztorach i kościołach dokonywanych przez szwedzkich żołnierzy, a poznańscy luteranie podjęli nawet próbę odzyskania pałacu Górków, chcąc ponownie odprawiać tam swoje nabożeństwa ${ }^{23}$. W Kronice Bernardynów poznańskich zanotowano:

Okrutny wróg wiary katolickiej i zacięty nieprzyjaciel wolności skierował swoją podstępną truciznę na duchowieństwo, nachodząc i zajmując pałace oraz dobra ziemskie szlachty, bezczeszcząc i okradając kościoły. Między innymi i nasz kościół poznański spalił doszczętnie,

19 Dzieje Poznania do roku 1793, s. 674.

20 O. Kiec, op. cit., s. 35.

21 Zob. K. Ja ro ch ow ski, Wielkopolska w czasie pierwszej wojny szwedzkiej odr. 1655 do 1657, Poznań 1864, s. 36-37.

22 Kronika poznańskich Karmelitów Bosych, s. 75.

23 Kronika Benedyktynek poznańskich, s. 174. 
podłożywszy ogień pod ołtarze, a z klasztoru zniszczonego wypędził wszystkich zakonników, wyprowadził na most na Warcie i dzikiemu żołdactwu kazał strącić do wody za namową niektórych heretyków"24.

Kroniki zakonów mieszczących się w Poznaniu barwnie oraz dosadnie opisywały tego typu incydenty. Dzięki wstawiennictwu swojej żony, komendant szwedzki rozkazał zaledwie wychłostać kilku zakonników, natomiast jednego zastrzelono, a pozostałych wygnano z miasta. Z kolei klasztor benedyktynek poznańskich został „tylko” ograbiony przez Szwedów. Natomiast położenie innych klasztorów oraz kościołów było znacznie gorsze, ponieważ przygotowując Poznań do obrony, spalono przedmieścia, w tym kościoły, klasztory i szpitale ${ }^{25}$ znajdujące się poza murami miejskimi, gdyż mogłyby służyć atakującym jako schronienie i punkt obserwacyjny miasta.

W kwietniu 1656 r. zakonników wszystkich klasztorów zwołano do ratusza i nakazano im natychmiast opuścić Poznań: „Wielu bowiem dysydentów z nienawiścią do wiary z hałasem wołało, że należy mnichów, gdy będą przeprowadzani przez most, wrzucić do rzeki”26. Kazimierz Jarochowski zaobserwował: „Smutny to musiał być widok owego miasta oszańcowanego, z popalonemi przedmieściami, przepełnionego obcem żołnierstwem, z opustoszałemi klasztorami i kościołami, z uciśnioną, zgnębioną, zmuszoną do milczenia ludnością polską, a panoszącą się, nastającą na nią bezczelnie ludnością obcą"27. Głos ten niekoniecznie był bliski prawdzie, chyba że autor miał na myśli samych żołnierzy szwedzkich i brandenburskich jako „ludność obcą”. Warto dostrzec pewną informację zawartą w Kronice poznańskich Karmelitów Bosych. Jej autor wspominał o kalwiniście pochodzenia szkockiego Jakubie Fergusonie, który miał bronić poznańskich karmelitów przed żołnierzami szwedzkimi i z własnych pieniędzy odkupywał dobra klasztorne zagarnięte przez Szwedów, które później oddawał zakonnikom. Miał też zaopatrywać karmelitów i innych poznańskich zakonników w żywnośćc ${ }^{28}$. Stanowi to dowód, iż nie wszyscy protestanci pałali nienawiścią do katolików i do duchownych, którzy najbardziej byli przeciwni innowiercom. Trzeba zaznaczyć, że opinia o poznańskich protestantach w połowie XVII w. nie była jednoznaczna oraz że ciężko znaleźć dowody, iż tylko za ich namową szwedzcy i brandenburscy okupanci niszczyli katolickie kościoły i klasztory: „Są tacy, co z pewnością utrzymują, że widzieli, jak niektórzy z heretyckich mieszczan poznańskich odprawiali nabożeństwa do diabła. To dla przestrogi dla potomnych należało spisać, nie należy jednak każdemu

\footnotetext{
24 Kronika Bernardynów poznańskich, s. 186-187.

25 O. Ki e c, op. cit., s. 37.

26 Kronika poznańskich Karmelitów Bosych, s. 80.

27 K. Ja roch ow ski, Wielkopolska w czasie pierwszej wojny szwedzkiej..., s. 79.

28 Kronika poznańskich Karmelitów Bosych, s. 79.
} 
w duchu w to wierzyć" - czytamy w Kronice ${ }^{29}$. Zresztą sami zakonnicy powątpiewali w te pogłoski rozgłaszane w Poznaniu.

Szwedzi oddali Poznań w 1656 r. Brandenburczykom: „W tymże roku po Wielkiej Nocy wyszli Szwedzi z Poznania a na to miejsce zaraz Mardeburczyk nastąpił - jeszcze gorszy niż Szwed, bo Szwedzi wżdy przedmieścia telko palili i kościoły dla szańców rozbierali. [...] Mardeburczyk zaś spalił co naprzedniejsze kościoły i klasztory: 14 kościołów pod ten czas zniesiono, klasztorów - 5 - Bernardyny, Klarki, Franciszkany, Bosaki i Karmelity od Bożego Ciała"30. Brandenburczycy, otrzymawszy Poznań w wyniku porozumienia ze Szwedami, od razu przystąpili do zaprowadzenia swoich porządków. Jednym z nich było niszczenie kościołów wewnątrz murów miejskich. Uważali, że ich wieże posłużą atakującym jako punkty orientacyjne przy ostrzale artyleryjskim. Brandenburczycy dopiero w $1657 \mathrm{r}$. zostali zmuszeni do opuszczenia miasta przez pospolite ruszenie ${ }^{31}$. Polskie oddziały nie zapisały się wcale dobrze w pamięci poznańskich mieszczan, a złe zdanie o żołnierzach walczących ze Szwedami pogorszyli żołnierze cesarscy, idący przez Poznań na pomoc Janowi Kazimierzowi. Ich zachowanie dało się we znaki również klasztorom ${ }^{32}$. W tym miejscu nasuwa się pytanie, kto tak naprawdę był gorszy - czy protestancki Szwed/Brandenburczyk, czy katolicki Polak lub Austriak? Podejmując próbę wyjaśnienia współpracy innowierców z okupantami tak szwedzkimi, jak i brandenburskimi, można zaryzykować twierdzenie, że zdrada i „kolaboracja” były udziałem tych protestantów, którzy bardzo późno osiedlili się w Poznaniu i okolicach bądź w Wielkopolsce ${ }^{33}$, a którzy często pochodzili (uciekali) z ziem pod panowaniem Habsburgów i mieli dużo sympatii do Szwedów, jako obrońców ich wiary, w trakcie wojny trzydziestoletniej. Natomiast protestanci lepiej zintegrowani ze społeczeństwem ziem polskich, a zwłaszcza mający w Rzeczypospolitej interesy ekonomiczne, dochowywali wierności Janowi Kazimierzowi i współobywatelom miasta, w którym żyli. Decydujące było zachowanie w konkretnych sytuacjach, a nie względy „ideowe”. „Obcy” niekoniecznie był z definicji „wrogiem”34. Przystoi ponownie przywołać historię poznańskiego kupca Fergusona, która byłaby potwierdzeniem tezy, że walka z żołnierzami szwedzkimi nie była wojną religijną, lecz obroną swojego domu przed obcym najeźdźcą ${ }^{35}$. Godne zaznaczenia jest to, że postawa społeczeństwa Rzeczypospolitej wobec obcego najeźdźcy nie była tylko wynikiem najazdu szwedzkiego, ale wszystkich wojen prowadzo-

29 Ibidem, s. 81.

30 Kronika Benedyktynek poznańskich, s. 183.

31 Zob.Z. Pilarczyk, M. Dan ielewski, K. Kościel niak, Wojenny Poznań. Fortyfikacje i walki o miasto do XVIII wieku, Poznań 2017, s. 188-193.

32 Ibidem, s. 185.

33 Przykładem może być Jan Amos Komeński z Leszna.

34 Zob. J. Dworzaczkowa, Reformacja a problemy narodowościowe..., s. 79 i n.

35 Kronika poznańskich Karmelitów Bosych, s. 79. 
nych przez państwo polsko-litewskie w połowie XVII w. z wrogiem różnym wyznaniowo. Aczkolwiek na zmianę nastrojów największy wpływ miała rekatolicyzacja oraz konkretne zachowania. Dodatkowo na podkreślenie zasługuje kwestia samych działań wojennych, które rządzą się swoimi prawami - żołnierz nie patrzy na wyznanie, narodowość czy też sytuację społeczno-ekonomiczną, tylko bierze, co chce, i to, co według niego mu się należy za narażanie się na niebezpieczeństwo.

Niezbędne nakreślenia jest, że na życie codzienne ówczesnych mieszkańców Poznania najsilniejszy wpływ miała działalność kontrreformacyjna Kościoła, szczególnie w dziedzinie kształtowania obyczajów. Mogła ona prowadzić do wzrostu niechęci pod adresem różnowierców. Działalność ta przejawiała się przeważnie w dążności do katolicyzacji obyczajów, w nakładaniu na wszystkie warstwy społeczne propagowanych przez Kościół norm określających sposób życia oraz zasady etyczne ${ }^{36}$. Jolanta Dworzaczkowa wymienia wiele powodów przechodzenia z protestantyzmu na katolicyzm (konwersji), podkreślając, że pozostanie przy wyznaniu ewangelickim wymagało prawdziwego samozaparcia i odwagi: „Oznaczało niemal całkowitą rezygnację z publicznej działalności [...], ograniczenia w wyborze współmałżonka, jeśli chciało się przekazać dzieciom swoją wiarę. Konieczne było ponoszenie dużego wysiłku finansowego, nie tylko na utrzymanie zborów, ale na opłaty dla katolickiego duchowieństwa, kary, grzywny i po prostu łapówki. Zdarzało się również zagrożenie osobistego bezpieczeństwa. Bardzo kuszące było uniknięcie tych wszystkich uciążliwości przez przejście na stronę silniejszego" ${ }^{37}$. Zdanie to wyjaśnia powody podejmowania decyzji o konwersji. Przejawem rekatolicyzacji w Poznaniu było wybudowanie okazałego kościoła Jezuitów, podczas gdy protestanci z trudem wyjednali sobie prawo dalszego pobytu w mieście w grudniu 1657 r. Na przestrzeni XVII w. coraz wyraźniej było widoczne ograniczanie wpływu różnowierców na stosunki wewnętrzne w Poznaniu. Dawną pozycję zachowali tylko ewangelicy, bracia czescy zostali zaś zredukowani do grupy kilkudziesięciu osób. W Poznaniu nie było już wyznawców kalwinizmu. Z czasem dysydenci poznańscy zaczęli się izolować w obrębie własnych gmin wyznaniowych, starając się unikać konfliktów z katolikami oraz koncentrując się na działalności gospodarczej. Jolanta Dworzaczkowa wskazała, iż po potopie dysydenci znaleźli się w ciężkim położeniu, gdyż zmieniły się nastroje społeczeństwa katolickiego: „Z doświadczeń wojennych wyciągnięto wnioski, że dla bezpieczeństwa państwa potrzebna jest jednolitość wyznaniowa, współwyznawcy wrogów są ich naturalnymi sojusznikami, a za ocalenie Rzeczypospolitej należy odwdzięczyć się Opatrzności tępieniem herezji” ${ }^{38}$. Ciężkie doświadczenia potopu szwedzkiego przyczyniły się do tego, jednak to katolicy i ich duchowni byli równie winni zaistniałej sytuacji, co różnowiercy.

36 Dzieje Poznania do roku 1793, s. 672.

37 J. D wor zac zkow a, Konwersje na katolicyzm szlachty ewangelickiej..., s. 99.

38 Ibidem, s. 96-97. 
To właśnie katolicy ograniczali prawa protestantów i Żydów, nie dając im swobód, jakie przysługiwały im samym, m.in. praw miejskich.

$\mathrm{Na}$ tle zachodzących procesów katolicyzacji życia codziennego uderzający jest fakt jednoczesnego utrzymywania się w tym okresie w społeczeństwie miejskim Poznania tolerancji religijnej w stosunku do będących w mniejszości protestantów. Kronika Benedyktynek poznańskich zanotowała precedens podwójnych nabożeństw przez kilka miesięcy w kościele sióstr Benedyktynek w języku polskim i niemieckim z kazaniami w tych dwóch językach ${ }^{39}$. Po potopie szwedzkim Poznań zaliczał się do nielicznych miast w Rzeczypospolitej, które przyjmowały do prawa miejskiego dysydentów, także w reskrypcie Jana Kazimierza z 1658 r. zapewniono dysydentom w Poznaniu dostęp do urzędów i do senioratów w cechach. Jak podaje Józef Łukaszewicz: „Po odzyskaniu Poznania z rąk nieprzyjaciela, Jan Kazimierz pragnąc wyludnione miasto na nowo mieszkańcami zapełnić nakazał magistratowi, aby dyssydentów mających zamiar osieść w tem mieście do prawa miejskiego przypuszczał. W tym samym 1658 r. postanowił, aby dyssydenci w Poznaniu osiedli, lub osiadający, mieli przystęp do urzędów miejskich i do senioratów w cechach”0 Podobne zarządzenie wydał w $1710 \mathrm{r}$. August $\mathrm{II}^{41}$, zastrzegając, aby owi przybysze byli katolikami, co nie zawsze było przestrzegane. Trzeba zaznaczyć, że w późniejszym czasie formalnie uprawnienia dla dysydentów poznańskich zostały cofnięte, a szczególnie ostrą walkę przeciwko uprzywilejowaniu niekatolików prowadziło na początku XVIII w. biskupstwo poznańskie ${ }^{42}$.

W całej strukturze narodowościowej miasta ${ }^{43}$ oraz w istniejących podziałach religijnych jedynie Żydzi byli celem stałych ataków ze strony mieszczan i Kościoła ${ }^{44}$. W Poznaniu występowała znaczna gmina żydowska, która zajmowała zwarty teren ${ }^{45}$. Okres rozkwitu gminy żydowskiej przypadał na drugą połowę XVI w., liczyła ona wtedy 1500 osób, a na podstawie lustracji z 1565 r. wiadomo, iż zamieszkiwały one w 50 domach własnych,

39 Kronika Benedyktynek poznańskich, s. 184.

40 J. Łukaszewicz, Obraz historyczno-statystyczny..., s. 62.

41 Ibidem, s. 63-64.

42 Dzieje Poznania do roku 1793, s. 674.

43 W Poznaniu oprócz Polaków mieszkali Niemcy (osiedlający się od XIII w.), Żydzi (przybywający do miasta od XIII w.), Szkoci (od XVI w.), Włosi (od XV-XVI w.), Grecy (od XVI w., w małej liczbie). Zob. J. Łukaszewicz, Obraz historyczno-statystyczny..., s. 66-108.

44 O działalności antyżydowskiej zakonu karmelitów zob.: J. W i s s i oł ow $s$ ki, Z okien rezydencji karmelitów. Żydzi wświetle kroniczki rezydencji karmelitów trzewiczkowych z ul. Żydowskiej, „Kronika Miasta Poznania” 2006, nr 3, s. 123-137.

45 M. Bogucka, H. Sa ms on owicz, op. cit., s. 469. Według raportu z 1619 r., sporządzonego dla króla, liczbę Żydów w Poznaniu określa się na 3130 osób. Zob. Rewizja mieszkań żydowskich w Poznaniu, 1619 rok, [w:] Opisy i lustracje Poznania..., s. 59-65. Według spisu liczby ludności zobowiązanych do płacenia pogłównego w Poznaniu było w 1675 r. 847 Żydów, oprócz ślepych, chorych i tych, którzy „sobie zarobić nie mogą." Zob. Liczba ludności żydowskiej, podatników pogtównego w mieście Poznaniu, 1675 r., [w:] Opisy i lustracje Poznania..., s. 107. 
43 wynajętych oraz 4 domach należących do gminy i związanych z 2 synagogami ${ }^{46}$. Dzielnica żydowska mieściła się w północnej części miasta, na tyłach ul. Żydowskiej, i ograniczona była ul. Wroniecką oraz zabudową ulic Szewskiej i Przed Dominikanami. W efekcie ciasnej zabudowy w dzielnicy żydowskiej nierzadko wybuchały pożary, które rozszerzały się na całe miasto. Było to powodem przewlekłych i kosztownych dla gminy procesów ze strony władz miejskich, które zwykle przy tym żądały całkowitego usunięcia Żydów z Poznania $^{47}$. Żydzi w Poznaniu na początku XVII w. stanowili 10\% mieszkańców (tyle co Niemcy, którzy stanowili 9-10\% ${ }^{48}$. Nazywano ich „domowym nieprzyjacielem” i przypisywano najbardziej nieprawdopodobne praktyki, jak porywanie dzieci czy uprowadzanie kobiet. Uważano ich za sprawców wszystkich nieszczęść, wojen i klęsk, które spadały na miasto $^{49}$. Był to katalog tradycyjnych zarzutów, znany z innych miast.

W czasie wojen szwedzkich w połowie XVII w. poznańska gmina żydowska została zdziesiątkowana przez głód i epidemie, a potem w wyniku oskarżenia jej członków o kolaborację ze Szwedami stała się ofiarą pogromów ze strony mieszczan oraz oddziałów wojskowych. Liczba Żydów w Poznaniu spadła wówczas do 300 rodzin $^{50}$. Wojny połowy XVII w. wzmogły niechęć mieszczan do tej społeczności; po zakończeniu działań wojennych często zabiegali oni o usunięcie Żydów lub o ich przesunięcie na inne tereny w mieście i poza nim. Dochodziło też do licznych ataków na ludność żydowską, np. w 1659 r. tłum pod wodzą uczniów z kolegium jezuickiego napadł na dzielnicę żydowską w Poznaniu, plądrując ją i niszcząc. Podobne wystąpienia miały miejsce w latach 1662, 1663 i 1687, wszystkie inicjowane przez uczniów kolegium jezuickiego ${ }^{51}$. Zdarzało się, że Żydzi dawali podstawy, rzeczywiste lub wymyślone, do ataków na swoją społeczność. Przykładowo w latach pięćdziesiątych XVII w. niejaki Lewald Meier, wojski inflancki, posesor wsi Rybowo, miał swojego „prywatnego" faktora w osobie Żyda poznańskiego Szymka. Podczas najazdu szwedzkiego Meier przywiózł dużo swoich rzeczy do Poznania i ukrył je w piwnicy kamienicy Szymka, na które ten ostatni nie dał Meierowi żadnego potwierdzenia. Nie wiadomo, od kogo dowiedzieli się o tym Szwedzi, którzy wszystko zabrali. Po uwolnieniu miasta spod okupacji Meier zaczął mścić się na Szymku za stratę dobytku, ostatecznie zabierając mu towary, które przysłano dla niego z Gdańska, jako rekompensatę $e^{52}$. Jest to przykład - bez

\footnotetext{
46 A. Mich hałow ska, Między demokracją a oligarchią. Wtadze gmin żydowskich w Poznaniu i Swarzędzu (od potowy XVII do końca XVIII wieku), Warszawa 2000, s. 11.

47 Ibidem, s. 11-12.

48 M. Bogucka, H. Samsonowicz, op. cit., s. 468, 473.

49 Dzieje Poznania do roku 1793, s. 675.

50 A. Michałowska, op. cit., s. 14.

51 J. Łukaszewicz, Obraz historyczno-statystyczny..., s. 249-350.

52 Ł. Straszew ska, Żydzi poznańscy w czasach saskich, „Kronika Miasta Poznania” 1990, nr 3/4 (przedruk z KMP 1933, nr 4), s. 216. Jest to tylko zasygnalizowanie problemu, który musi być opisany w oparciu o analizę akt miejskich (w pewnej mierze też sejmikowych).
} 
zwracania uwagi na działania okupantów, którzy rabowali, co się dało - na szukanie winnych wśród Żydów.

Wielka wojna północna w początkach XVIII w. oraz związana z nią kolejna okupacja szwedzka w latach 1703-1709 przyniosła duże zniszczenia i załamanie gospodarcze miasta $^{53}$. Zniszczenia mogły mieć jeszcze większy zasięg niż w XVII w., ale trudno je opisać w świetle aktualnych badań. W momencie zajęcia miasta przez Szwedów we wrześniu 1703 r. część ludności miejscowej zamieszkującej zabudowania wewnątrz murów miejskich została częściowo wyparta z miasta przez szwedzką załogę, która okresowo liczyła nawet do kilku tysięcy żołnierzy ${ }^{54}$. W tym czasie w Wielkopolsce powtórzyła się prawie dokładnie sytuacja z czasów potopu. Józef Feldman uznawał, że większość dysydentów opowiedziała się po stronie Szwedów i Stanisława Leszczyńnkiego, ponieśli też konsekwencje przegranej ${ }^{j 5}$. W toku działań wielkiej wojny północnej nastąpiła nowa fala nienawiści do protestantów, tym gwałtowniejsza, że była odbiciem poczucia bezsilności i zagrożenia Rzeczypospolitej oraz wielkiego lęku przed Szwedami. Dodatkowo stosowane przez kler katolicki argumenty, że wszystkie klęski były karą Bożą za tolerowanie herezji, padały na podatny grunt. Ta optyka trafiała do szlachty i większości społeczeństwa Rzeczypospolitej. Przekonywająco przy tym brzmiały zarzuty, iż dysydenci wiążą się z obcymi mocarstwami, że to oni uniemożliwiają wewnętrzną zgodę w państwie ${ }^{56}$. Ta propaganda wojenna, rządząca się własnymi prawami, odgrywała istotną rolę w kształtowaniu postaw społeczeństwa Rzeczypospolitej. Chociaż jest to generalizowanie problemu. Wydaje się naturalne, że takie uogólnienia można przypisać szlachcie, ale czy mieszczanom? Wolno stwierdzić, że nie dotyczy to Poznania, gdyż retoryka szlachty i duchowieństwa nie do wszystkich mieszkańców miasta docierała, tym bardziej że część kaznodziejów głosiła, iż klęski w wojnach są karą $\mathrm{m}$.in. za winy popełnione przez szlachtę.

Poznańscy protestanci w drugiej połowie XVII w. nie mogli liczyć na wybudowanie zboru w Poznaniu. Luteranie uczęszczali więc do kościoła w Swarzędzu, a kalwiniści (ewangelicy reformowani) w Skokach, gdzie istniała duża gmina reformowana. Zmianę w dotychczasowej sytuacji przyniosła wielka wojna północna (1700-1721) i zajęcie Poznania przez Szwedów w 1703 r. ${ }^{57}$ Kapelani towarzyszący szwedzkim żołnierzom odprawiali w mieście nabożeństwa, z czego skorzystała również miejscowa grupa protestantów. Protestanci byli na tyle silni i zamożni, że zamierzali reaktywować w Poznaniu nabożeństwa ewangelickie dla mieszkańców (niekoniecznie sięgając po szwedzkich kapelanów). W tym

53 M. B a u m, Klasztor w mieście w świetle kronik Benedyktynek poznańskich 1607-1780, Lublin 2009, s. 217.

54 M. Kędelski, Dynamika i struktura ludności chrześcijańskiej miasta Poznania w XVIII wieku w świetle rejestracji podatkowej, „Rocznik Dziejów Społecznych i Gospodarczych” 1990/1991, t. 51/52, s. 60.

55 J. Feld man, Sprawa dysydencka za Augusta II, Kraków 1924 (odbitka z: „Reformacja w Polsce” R. III, 1924, nr 9-10, s. 89-116), s. 4-5.

56 J. Dworzaczkowa, Reformacja i kontrreformacja w Wielkopolsce, Poznań 1995, s. 352.

57 O. Kiec, op. cit., s. 39. 
celu zaadaptowali budynek miejskiej łaźni na dom modlitwy ${ }^{58}$. Wkrótce jednak urządzono dwa odrębne miejsca do sprawowania posług duchownych. Żołnierze szwedzcy zaadaptowali na potrzeby kultu dom przy strzelnicy miejskiej, natomiast poznaniacy odprawiali nabożeństwa w jednej z sal łaźni przy ul. Woźnej9. W Kronice Bernardynów poznańskich tak scharakteryzowane zostały te lata: „[...] lupienie miast i grodów, świętokradzkie łupienie kościołów, ucisk ludu, duchowieństwa i szlachty, pustoszenie folwarków, dokonywane ciągle przez Szwedów" ${ }^{60}$. Duchowni katoliccy podkreślali to, iż rabowane i niszczone są kościoły katolickie (gdyż innych, tak bogato wyposażonych, w mieście nie było) jako dopuszczanie się świętokradztwa przez różnowierców. Niemniej były to typowe działania armii w czasie wojny, niemające wiele wspólnego z celowym upokarzaniem katolików. Dotykały one tak samo kościoły, jak i domy ludności cywilnej. A raczej w większym stopniu cierpiała zabudowa świecka - dane źródłowe wskazują mianowicie, iż na skutek działań wojennych pod Poznaniem zostało niewiele budynków. Przedmieścia Poznania oraz takie dzielnice, jak Grobla, Dworce, Ogrody zostały częściowo spalone, a to, co zostało, zrujnowane na kwotę $150000 \mathrm{zł}^{61}$. Natomiast po lustracji z 1713 r. okazało się, że np. na Rybakach (dzielnicy Poznania) ostało się tylko siedem pustych domów, reszta spłonęła w wyniku działań zbrojnych lub od przypadkowego ognia ${ }^{62}$. Należy położyć nacisk na to, że to żołnierze szwedzcy byli autorami tychże sytuacji, a nie poznańscy protestanci, którzy tylko wykorzystali sposobności do swobody kultu religijnego. Stawianie żołnierzy szwedzkich oraz poznańskich różnowierców w jednym szeregu jest błędem. Dysydenci mieszkający w Poznaniu owszem czerpali z tej sytuacji, aczkolwiek nie można orzekać, że byli inicjatorami represji wobec katolików.

W latach 1700-1709 Poznań z przedmieściami liczył ok. 13000 mieszkańców. W samym śródmieściu liczba ludności chrześcijańskiej w latach 1701-1707 wahała się między ok. 2500 a 3750 osób $^{63}$. W 1709 r. w efekcie epidemii śmierć poniosło łącznie 9000 ludzi ${ }^{64}$. W Kronice poznańskich pisarzy miejskich pod rokiem 1709 zanotowano: „Bóg po trzykroć najlepszy, najpotężniejszy, zechciał za grzechy wymazać spośród żywych cały lud miasta

58 W. Krieg se is en, Ewangelicy polscy i litewscy w epoce saskiej (1696-1763). Sytuacja prawna, organizacja i stosunki międzywyznaniowe, Warszawa 1996, s. 77.

59 Ibidem, s. 39-40. W samym Poznaniu przychylność Szwedów dla protestantów, wprowadzenie regularnych nabożeństw dla nich były niedopuszczalne dla władz katolickich i dostatecznym powodem tym gwałtowniejszego prześladowania innowierców po odejściu Szwedów. M. Paradowska, Bambrzy. Mieszkańcy dawnych wsi miasta Poznania, Warszawa-Poznań 1975, s. 47-48.

60 Kronika Bernardynów poznańskich, s. 256.

${ }^{61}$ Specyfikacja szkód publicznych miasta Poznania, Archiwum Państwowe w Poznaniu [dalej: APP], Akta miasta Poznania [dalej: AmP] I 1690, k. 3.

62 Zob. K. Kościelniak, Plac Wiosny Ludów i okolice podczas osiemnastowiecznych dziatań wojennych, „Kronika Miasta Poznania” 2018, nr 2, s. 38 i n.

63 M. Kędelski, op. cit., s. 61.

64 Dzieje Poznania do roku 1793, s. 665. 
Poznania i wszystkich jego przedmieść i wsi" ${ }^{65}$. Jest to potwierdzenie tego, że dopuszczenie do wydarzeń w Poznaniu jest karą za grzechy mieszkańców pod postacią epidemii, która pochłonęła 75\% ludności miasta. Największe załamanie w liczbie ludności chrześcijańskiej zamieszkałej w śródmieściu datowano właśnie na lata 1709-1710, w śródmieściu mogło wówczas mieszkać co najwyżej 1500 chrześcijan ${ }^{66}$. Ze zniszczeniami wojennymi, zarazami, kontrybucjami wiązało się niewątpliwie znaczne wyludnienie śródmieścia, przedmieść i wsi miejskich ${ }^{67}$. Dopiero w roku 1713 śródmieście Poznania zaludniło się do ok. 2930 chrześcijan $^{68}$. Dotyczyło to także dysydentów i Żydów. August II, jak to zostało wcześniej podkreślone, w 1710 r. wydał zarządzenie o przyjmowaniu do prawa miejskiego obcych ${ }^{69}$, zastrzegając, aby owi przybysze byli katolikami, chociaż wśród osadników znajdowali się również niemieccy protestanci. Śmierć i zniszczenia dotykały wszystkich mieszkańców Poznania bez względu na wyznanie i prawdopodobnie to nieszczęście było powodem pewnej solidarności wśród nich.

W momencie zakończenia oblężenia Poznania (3 listopada 1704 r.) przez armię dowodzoną przez Johana Reinholda Patkula dochodziło do różnych wydarzeń, które przypisywano protestantom. Przykładowo w Kronice poznańskich Karmelitów Bosych można znaleźć interesujący fragment mówiący o tym, że:

W sam dzień Wszystkich Świętych nastąpiło zawieszenie broni ze Szwedami z miasta. [...] Następnego dnia zapłacił za to również nasz klasztor, gdy do gospodarstwa wszedł szwedzki żołnierz, jakoby zabrać rzeczy pozostawione przez nasze wojsko, opuszczające Poznań. W rzeczywistości takowych rzeczy nie było. Popadliśmy wówczas w ostateczną ruinę i konwent ledwie utrzymywał się przy życiu. [...]. Trzystu żołnierzy szwedzkich przebywało w środku. Pełni zaciekłości wobec katolików i nas, którzy sąsiadowaliśmy z ich cmentarzem na Łysej Górze Luterskiej, mieli nawet zamiar zrównać nasz kościół z ziemią ${ }^{70}$.

Duchowni katoliccy typowe działania armii podczas wojny odczytywali jako atak na Kościół katolicki. Często zdarzało się, że przywoływano motyw nienawiści między protestantami a katolikami. Retoryka ta ukazywała się w pismach zakonników, którym wydawało się, że każdy protestant jest „złem wcielonym” i pragnie tylko zabijać katolików, a zwłaszcza duchownych katolickich. Dyktował to lęk i nauczanie Kościoła katolickiego.

${ }_{65}$ Kronika poznañskich pisarzy miejskich, oprac. J. W i e si o ło w ski, Poznań 2004, s. 97.

66 M. Kędelski, op.cit., s. 61.

67 Ibidem, s. 59.

68 Ibidem, s. 61.

${ }_{69}$ J. Łukaszewicz, Obraz historyczno-statystyczny..., s. 63-64.

$70 \quad$ Kronika poznańskich Karmelitów Bosych, s. 186. 
Niemniej był to po prostu ogólny pogląd, swoista propaganda, która zmierzała do znalezienia winnego położenia, w jakim znalazły się miasta i cała Rzeczpospolita.

W Kronice Bernardynów poznañskich można odnaleźć użalanie się zakonników na to, co ich spotkało ze strony Szwedów: „Co i ile klasztor poznański, narażony na ciągłe przykrości ze strony Szwedów, których podjudzali miejscowi protestanci, wycierpiał wskutek prześladowania zakonów żebraczych, zajmowania cel przez kobiety z mężami, żołnierzami armii szwedzkiej, grzebania zmarłych Szwedów w ogrodzie [...]"1․ Często duchowni katoliccy obwiniali protestantów o inicjowanie tego typu działań. Prawdą jest, że Szwedzi przebywający w Poznaniu czynili kroki mające na celu polepszenie warunków życia protestantów w mieście. Tutaj powstaje pytanie, czy poznańscy protestanci byli inicjatorami tego typu działań, czy wyłącznie z nich korzystali? Odpowiedź jest trudna. 25 lutego 1708 r. Szwedzi aresztowali i osadzili w więzieniu prezydenta miasta Pawła Parkana, ponieważ nie zamierzał przyjąć protestantów do rady miejskiej ${ }^{72} .15$ czerwca tegoż roku komendant szwedzki aresztował całą radę miejską Poznania, gdyż nie chciała do swojego grona wprowadzić dysydentów. Dalej do domu każdego z rajców posłał po 12 żołnierzy w celu egzekucji ich majątków, dodatkowo pobrał od rady miejskiej 30000 tynfów ${ }^{73}$. Podobna sytuacja miała miejsce 16 lipca 1708 r. ${ }^{74}$, kiedy Szwedzi próbowali siłą umieścić w radzie miejskiej protestantów. W tym zakresie rodzi się pytanie o ich motywację. Prawdopodobnie chodziło Szwedom bardziej o promowanie żywiołu niemieckiego i umniejszanie roli Polaków w radzie.

Ponadto można odnaleźć przekazy dotyczące zabójstw Szwedów w Poznaniu w czasie ich przebywania w tym mieście. Kazimierz Jarochowski podaje, że za zabicie rajtara szwedzkiego winny, którego ujęto, został przywiązany do nóg końskich i wleczony $1,5 \mathrm{~km}$ przez miasto $^{75}$. Inny przypadek to zastrzelenie w listopadzie 1704 r. na moście Chwaliszewskim oficera z pułku wojewody wileńskiego Kazimierza Jana Sapiehy, niejakiego Lausona, i jego ordynansa. Sprawców nie znaleziono. Jednak Szwedzi zemścili się na całym mieście prześladowaniami oraz kontrybucjami ${ }^{76}$. Kolejny przykład: 26 lutego 1708 r. żołnierz szwedzki na Garbarach zastrzelił się w łóżku „z niewiadomej przyczyny”77. Poruszone przykłady świadczą raczej o nienawiści do obcego okupanta, a nie do dysydenta, co też potwierdza tezę, że mieszkańcy Poznania całą swoją nienawiść kierowali wobec okupanta,

71 Kronika Bernardynów poznańskich, s. 256-257.

72 J. Łukaszewicz, Obraz historyczno-statystyczny..., s. 366.

73 Ibidem, s. 366.

74 APP, AmP I 72, s. 1742.

75 K. Ja roch owski, Oblężenie miasta Poznania przez Patkula. Epizod kampanii roku 1704, Poznań 1879, s. 28-29.

76 Ibidem, s. 28-29.

77 J. Łukaszewicz, Obraz historyczno-statystyczny..., s. 366. 
a nie protestantów mieszkających w mieście. Gdyby było inaczej, to dochodziłoby do zabójstw mieszczan innego niż katolickie wyznania. Tak wyróżniano „obcych”, oszczędzano „swoich”.

Po klęsce Szwedów pod Połtawą w 1709 r. garnizon szwedzki opuścił Poznań, likwidując jeden dom modlitwy przy strzelnicy. To samo władze miejskie zleciły poznańskim ewangelikom, czyli usunięcie domu modlitwy w łaźni miejskiej, lecz ci odmówili. W powyższej sprawie magistrat zwrócił się do sejmiku w Środzie Wielkopolskiej z prośbą o wydanie decyzji w tej materii. Ten nakazał likwidację domu modlitwy. Burmistrz zebrał grupę ludzi i w styczniu 1710 r. wdarto się do budynku przy ul. Wodnej, w którym odbywały się nabożeństwa. Część wyposażenia zniszczono, a resztę przekazano na rzecz fary ${ }^{78}$. Kiedy do miasta wkroczyły wojska saskie, składające się w większości z protestantów, ponownie otwarto ewangelicki dom modlitwy. Wtedy sejmik w Środzie próbował nie dopuścić do dysydenckich nabożeństw ${ }^{79}$. Stan ten trwał do 1716 r., gdy z kolei Poznań zajęły wojska konfederatów tarnogrodzkich ${ }^{80}$.

Należy zauważyć, że poznańscy dysydenci w okresach wojen i stacjonowania w mieście obcych (także wyznaniowo) armii nie dali się wykorzystać jako narzędzie uciskania katolików. W ten sposób kwestia dysydencka nie stała się w Poznaniu stymulatorem napięć. Taki był ówczesny system wartości funkcjonujący w wielu miastach Rzeczypospolitej. Poznań nie był tutaj wyjątkiem.

Najbardziej znienawidzoną przez mieszkańców Poznania grupą ludzi byli Żydzi, którzy poprzez swoją odmienność, często współpracę ze Szwedami i donosy na polską szlachtę zyskali nienawiść zarówno ze strony szlachty, jak i mieszczan poznańskich ${ }^{81}$. W tamtym czasie nie było to zjawisko odosobnione, tym bardziej że Szwedom łatwiej się było porozumieć z aszkenazyjczykami. Żydzi mieli opinię zdrajców i szpiegów, znaną już z czasów potopu. Potwierdzili ją też podczas wielkiej wojny północnej, gdyż oddawali swoje usługi zawsze tej stronie, która akurat w danej chwili zwyciężała oraz trzymała władzę ${ }^{82}$. W trakcie oblężenia miasta Poznania przez wojska pod dowództwem Patkula komendant szwedzki rozkazał każdemu mieszkańcowi zaopatrzyć się w wodę i haki, na wypadek podpalenia zabudowań. Żydom natomiast zlecono specjalne zadanie polegające na „przytłumianiu

78 W. Kriegseisen, op. cit., s. 77.

79 Laudum sejmiku województwa poznańskiego i kaliskiego z uniwersatu Augusta II w Środzie 11 grudnia 1713 r., [w:] Akta sejmikowe województw poznańskiego i kaliskiego. Lata 1696-1732, wyd. M. Zw ie r zykowski, Poznań 2008, s. 743: „Zalecamy jm. Panu marszałkowi koła naszego, aby list napisał do jm. Pana komendanta poznańskiego imieniem koła naszego ratione łaźni, którą praeoccupavit, żeby się do niej interesować nie chciał. Do jm. zaś księdza proboszcza poznańskiego uprosiliśmy jm. Pana marszałka o napisanie listu, ażeby tę łaźnię zapieczętował przy woźnym i szlachcie, inquantum by panowie dysydenci tam nabożeństwo odprawiać chcieli".

80 O. Kiec, op. cit., s. 40.

81 E. Straszewska,op.cit., s. 217.

82 Ibidem. 
bomb” spadających na miasto ${ }^{83}$. Po wyjściu Szwedów Trzeci Porządek miasta Poznania domagał się od Żydów: „[...] aby w święta nasze tak publicznych handlów zaniechali, gdyż stąd wielka ujma się dzieje obywatelom i kupcom poznańskim, gdzie w święta kupujący lud znęciwszy się do nich zawsze tam ciągnie, mając z nich w uroczystości nasze kupienia wygodę"84. Dotyczy to sytuacji, kiedy Żydzi, nie obchodząc i nie uwzględniając świąt katolickich, handlowali jak co dzień, a że ze względu na to, iż pozostali kupcy mieli swoje kramy pozamykane, nie podobało się to ani tymże kupcom, ani władzom miasta. Ten sam Trzeci Porządek na przełomie 1714 i 1715 r. zalecał:

Żydzi prosimy, aby w karności trzymani byli zabraniając im jako złośliwym ludziom targów w święta kupna na Rynku i omni modo im szkodzić. A naprzód wiadomo to, że Żydzi jako to rzeźnicy zabiwszy wołu albo inne bydlę zad chrześcijanom przedają; prosiemy tedy, aby mieszczanom i obywatelom miasta takowego mięsa żydowskiego kupować pod winą nie godziło się, kupione skonfiskować i tego, co kupił, karać. Niech się im lepiej ześmiergnie! Ludzi, którzy im w sabasy posługują, popisać i od służby żydowskiej aby płacili, nakazać, jako to i praczki żydowskie, co wodę miejską paskudzą

W tym fragmencie widać, że starano się ograniczać działalność Żydów, szczególnie tę związaną z ich wiarą. Być może była to jakaś forma zmuszenia ich do przestrzegania zakazu handlu w święta katolickie. Ostatecznie trudno było wprowadzić te zalecenia w życie. A były one znane i z innych miast.

Warto zaakcentować, że na początku XVIII w. Żydzi wielkopolscy tak samo ponieśli poważne straty. Były one wynikiem epidemii, pożarów, kontrybucji, wreszcie działań zbrojnych. Okupacja Poznania przez Szwedów, epidemia w 1709 r., kontrybucja nałożona przez Chryzostoma Gniazdowskiego w 1716 r. oraz pożar w roku następnym ${ }^{86}$ były dla Żydów nieszczęściem ${ }^{87}$. Po wielkiej wojnie północnej dzielnica żydowska w Poznaniu była zniszczona, co wykorzystały władze miejskie, zezwalając na odbudowę tylko 86 domów żydowskich oraz nakazując ogrodzenie dzielnicy żydowskiej „palikami”88. Widać z tego, że niechęć do Żydów była większa niż do dysydentów, dlatego że budzili większe poczucie obcości. Żydzi różnili się wyglądem, mową, obyczajami. Z kolei dysydenci byli

83 J. Eukaszewicz, Obraz historyczno-statystyczny..., s. 362.

84 Trzeci Porzadek domaga się poprawy stosunków w mieście, Poznań 24.10.1711 r., [w:] Opisy i lustracje Poznania..., s. 131.

85 Stan miasta Poznania w relacji Trzeciego Porzadku, 1714/1715 r., [w:] Opisy i lustracje Poznania..., s. 149.

86 Pretensje Poznania przeciw Żydom, APP, AmP I 288, k. 213-224. W innym miejscu otrzymujemy informację, że w wyniku pożaru dzielnicy żydowskiej w 1717 r. zniszczony został mur miejski na odcinku 15 metrów. Zob. ibidem, k. 208-212. Spór miasta z Żydami zob. APP, AmP I 2250, k. 310-311.

87 A. Michałowska, op.cit., s. 17.

$88 \quad$ Ibidem, s. 17. 
wizualnie i kulturowo podobni do katolików. Stąd ta większa niechęć do Żydów, właśnie ze względu na ich odmienność. A wojny jeszcze bardziej wzmogły tę niechęć. Sama kwestia Żydów w Poznaniu jest trochę odrębna, gdyż posiadali oni inny status formalny, udokumentowany przywilejami wydawanymi przez różne podmioty władzy. A wzrost nastrojów antyżydowskich w mieście, zwłaszcza na początku XVIII w., był potencjalnie spowodowany pobytem Szwedów i tym, że Żydzi mogli ich traktować jak ludzi ułatwiających im życie i działalność. Jednak aby w pełni to potwierdzić, konieczne są dalsze badania.

Podsumowując powyższe rozważania, w drugiej połowie XVII i w początkach XVIII w. Poznań doznał wielu szkód w związku z działaniami wojennymi i ich rezultatami, a także z klęskami żywiołowymi ${ }^{89}$. Niezwykle niszczący przez swoje bezpośrednie i pośrednie skutki okazał się najazd szwedzki z 1655 r. Wielka wojna północna przyniosła następne zniszczenia i dalsze załamanie rozwoju gospodarczego miasta. Te dwa konflikty wywołały pewien nieoczekiwany skutek, mianowicie protestanccy mieszkańcy i duchowni Poznania stali się obiektem wymuszeń majątkowych ${ }^{90}$. Dopuszczali się ich nie tylko polscy szlachcice czy księża katoliccy, ale także oddziały wojskowe różnych państw kwaterujących w Poznaniu, często pod szyldem obrony miejscowych protestantów. Dotykało to również Żydów i katolików. Te przypadki miały wpływ na postawę protestantów wobec Rzeczypospolitej, którzy w reakcji na pogardę okazywaną im przez Polaków (głównie przez szlachtę) umacniali swą protestancką i mieszczańską tożsamość, eksponując coraz bardziej jej niemiecki charakter $^{91}$ i izolując się w swych gminach wyznaniowych. Sami protestanci już od XVI w. byli znaczącą grupą wyznaniową Poznania i choć zawsze byli mniejszością, to o ich znaczeniu decydowały uwarunkowania polityczne oraz ekonomiczne w zależności od okresu historycznego. Byli bogaci i wpływowi, co zapewniało im wysoki status społeczny oraz wpływy niejednokrotnie większe niż w przypadku katolików i Żydów². Wszakże wydaje się, że większe zajścia na tle religijnym w Poznaniu nie występowały. Wojny i okupacje nie miały wpływu na trwałe pogorszenie się wzajemnych relacji między protestantami a katolikami. Na wyróżnienie zasługuje fakt, że protestanccy i katoliccy mieszkańcy miasta nie dali się wciągnąć w przewlekły konflikt religijny, a kwestia dysydencka nie stała się przyczyną niepokojów. Było to może świadectwo utrzymywania się klimatu tolerancji w wielu miastach Wielkopolski na pograniczu brandenburskim i śląskim. Jest to problem wart bliższego zbadania.

89 Dzieje Poznania do roku 1793, s. 621.

90 M.in. w 1715 r., kiedy Swarzędz, gdzie znajdował się najbliższy zbór, w którym poznańscy protestanci mogli odprawiać swoje nabożeństwa, przeszedł w ręce nowego właściciela, a ten wypowiedział umowę na użytkowanie świątyni. Zmiana decyzji nastąpiła dopiero po otrzymaniu znacznej sumy pieniędzy.

91 O. Ki ec, op. cit., s. 42.

92 Ibidem, s. 7. 


\section{BIBLIOGRAFIA}

\section{Źródła rękopiśmienne:}

Archiwum Państwowe w Poznaniu, Akta miasta Poznania: I 72; I 288; I 1690; I 2250.

\section{Źródła drukowane:}

Akta sejmikowe województw poznańskiego i kaliskiego. Lata 1696-1732, wyd. M. Zwierzykowski, Poznań 2008.

Kronika Benedyktynek poznańskich, oprac. A.B. Tomczak OFM, J. Wiesiołowski, Poznań 2001.

Kronika Bernardynów poznańskich, oprac. A.B. Tomczak OFM, J. Wiesiołowski, Poznań 2002.

Kronika poznańskich Karmelitów Bosych, oprac. P.F. Neumann OCD, Poznań 2001.

Kronika poznańskich pisarzy miejskich, oprac. J. Wiesiołowski, Poznań 2004.

Opisy i lustracje Poznania z XVI-XVIII wieku, oprac. M.J. Mika, Poznań 1960.

\section{Opracowania:}

Baum M., Klasztor w mieście w świetle kronik benedyktynek poznańskich 1607-1780, Lublin 2009.

Bogucka M., Samsonowicz H., Dzieje miast i mieszczaństwa w Polsce przedrozbiorowej, Wrocław 1986.

Dworzaczkowa J., Konwersje na katolicyzm szlachty ewangelickiej wyznania czeskiego w Wielkopolsce w XVI i XVII wieku, „Odrodzenie i Reformacja w Polsce” 2006, t. 50, s. 89-100.

Dworzaczkowa J., Reformacja a problemy narodowościowe w przedrozbiorowej Wielkopolsce, „Odrodzenie i Reformacja w Polsce" 1978, t. 23, s. 79-101.

Dworzaczkowa J., Reformacja i kontrreformacja w Wielkopolsce, Poznań 1995.

Dzieje Poznania do roku 1793, t. 1, red. J. Topolski, Warszawa-Poznań 1988.

Feldman J., Sprawa dysydencka za Augusta II, Kraków 1924 (odbitka z: „Reformacja w Polsce” R. III, 1924, nr 9-10, s. 89-116).

Jarochowski K., Oblężenie miasta Poznania przez Patkula. Epizod kampanii roku 1704, Poznań 1879.

Jarochowski K., Wielkopolska w czasie pierwszej wojny szwedzkiej od r. 1655 do 1657, Poznań 1864.

Kędelski M., Dynamika i struktura ludności chrześcijańskiej miasta Poznania w XVIII wieku w świetle rejestracji podatkowej, „Rocznik Dziejów Społecznych i Gospodarczych” 1990/1991, t. 51/52, s. 57-89.

Kiec O., Historia protestantyzmu w Poznaniu od XVI do XXI wieku, Poznań 2015.

Kościelniak K., Plac Wiosny Ludów i okolice podczas osiemnastowiecznych dziatań wojennych, „Kronika Miasta Poznania" 2018, nr 2, s. 33-44.

Kriegseisen W., Ewangelicy polscy i litewscy w epoce saskiej (1696-1763). Sytuacja prawna, organizacja i stosunki międzywyznaniowe, Warszawa 1996.

Łukaszewicz J., Obraz historyczno-statystyczny miasta Poznania w dawniejszych czasach, t. I-II, Poznań 1838.

Michałowska A., Między demokracja a oligarchia. Wtadze gmin żydowskich w Poznaniu i Swarzędzu (od potowy XVII do końca XVIII wieku), Warszawa 2000.

Paradowska M., Bambrzy. Mieszkańcy dawnych wsi miasta Poznania, Warszawa-Poznań 1975.

Pilarczyk Z., Danielewski M., Kościelniak K., Wojenny Poznań. Fortyfikacje i walki o miasto do XVIII wieku, Poznań 2017.

Straszewska Ł., Żydzi poznańscy w czasach saskich, „Kronika Miasta Poznania” 1990, nr 3-4 (przedruk z KMP 1933, nr 4), s. 213-218.

Wiesiołowski J., Z okien rezydencji karmelitów. Żydzi w świetle kroniczki rezydencji karmelitów trzewiczkowych z ul. Żydowskiej, „Kronika Miasta Poznania” 2006, nr 3, s. 123-137. 